\title{
DETERMINATION WHETHER THERE IS ANY CORRELATION BETWEEN THE LEVELS OF STRATEGIC PLANNING ON MARKETING, TECHNOLOGICAL AND FINANCIAL PERFORMANCE OF BANK OF BARODA KENYA EAST AFRICA
}

\author{
Miriam Wanjiku Gichung'wa ${ }^{1 *}$, Thomas Ombui Nyakweba ${ }^{2}$, Peter Muthama Muchai ${ }^{3}$ \\ *1,2,3 Presbyterian University of East Africa, Kikuyu, Kenya, P.O Box 392-0902, Kikuyu, Kenya
}

*Corresponding Author: -

\begin{abstract}
: -
This study was undertaken with the primary purpose of determining whether there was any correlation between the level of strategic planning on marketing performance' technological performance and financial performance of bank of Baroda. To accomplish this task, data was collected from a sample of small number to present each of the bank's department and customers along with information from other Banks data base.

The focus was on correlation between strategic planning and marketing performance, financial performance and technological performance.

The research was carried out using a questionnaires, opinions and observations, based upon a purposive and simple sample of the bank in the target population. The data was analyzed using the package of social science of statistics and analysis of Karl Pearson's coefficient of correlation as appropriate. The findings of this study revealed that there was correlation between the level of planning activities carried out by a financial institution and the performance of the bank as measured by the Return on Assets, the Return on Equity, and the Net Interest Margin, customer satisfaction, quality of services, product quality, brand, brand name, time frame, costs, efficiency and effectiveness. The findings also revealed that there was correlation between the level of planning carried out by the financial institution and the management characteristics measured. The findings also found correlation between the level of planning carried out and the size of the bank's departments within the target population. These results were consistent and reaffirmed several prior studies indicating that there was correlation between the level of impacts of strategic planning and performance of the bank output.
\end{abstract}

The findings also found correlation between the level of planning carried out and the size of the bank's departments within the target population. On overall the researcher found out that there was a correlation between strategic planning and Marketing, Financial, Technological performance.

Key words: Strategic Planning, Correlation, Performance 


\section{BACKGROUND OF THE STUDY}

Bank of Baroda (India) Ltd opened its first overseas Branch in Mombasa, Kenya in 1952; subsequently it opened its second branch in Nairobi in 1953. Eight more branches have been opened in various towns in Kenya, Thika in 1968, Kisumu - 1965, Eldoret, Nakuru and in Nairobi at Koinange Street, Industrial Area and Sarit centre. Shortly the bank will open new more branches at Nyali Mombasa and Kakamega. This bank was incorporated locally in 1992 under Act of parliament and trades in Kenya; it became subsidiary of the parent bank. This bank is now known as Bank of Baroda (Kenya) Ltd with its headquarters at Nairobi (Koinange Street) Kenya. Bank of Baroda (K) Ltd has grown its business from Ksh. 100 million to currently 34 Billion worth of business in the middle tier banks of Kenya. Market share is still small but there is a potential growth in Kenya. Bank of Baroda has sister banks in Tanzania and Uganda in East Africa and in several African countries. The parent bank has its presence in all continents of the world, Srivastava (2010).

The vision of bank of Baroda: To be the most respected and preferred financial service company, striving to enhance stakeholders value with care concern and competence.

Mission: To maximize customer satisfaction through well-trained staff and to strive to establish a mutually beneficial and long business relationship. To highlight various technology-based initiatives and embark upon Reinforcement campaign for promoting technology based offerings to customers- Srivastava (2010).

Organizations, through their planning set long-term strategies, which are converted into shortterm action plans to help achieve its long-term objectives. To this end, the importance of strategic planning and its impact on the overall performance and profitability cannot be over emphasized.

Companies now operate in vastly competitive and nonlinear environments, the value of a business lies increasingly in its ability to capture information and generate new ideas. According to (Kotler 2004), "an idea that is not dangerous is hardly worth calling an idea. The same can be said of a strategic plan. A great plan provokes. It takes chances. This eventually attracts customers and the market to one's brand." Therefore, there was a need for effective strategic planning in an organization. Firstly, we need to understand the concept of strategic planning. Strategic planning is an orderly thinking by senior managers or a group of them that formulates courses of action that can be implemented by anyone on schedule Mentzberg (1975).

Strategic planning is an offshoot of strategic management and is nowadays referred to as corporate planning. According to Olukanye (2001), "Strategic management is the management process by which policies are formulated and strategies are selected to achieve the goals and objectives of an organization". He argued that both concepts (strategic management and strategic planning) are often used interchangeably. To Kotler, strategic planning is "the managerial process of developing and maintaining a viable relationship between the organization and its environment, through the development of corporate purpose, objectives and goals, growth strategies and business portfolio plans for company-wide operations". Strategic planning is also seen as “a company's planning process towards what it wants to achieve in the long-term. It must convey a significant stretch for the company, a sense of direction, discovery and opportunity that can be communicated as worthwhile to all employees. It should not focus so much on today's problems but rather on tomorrow's opportunities Kotelnikov (2007).

Strategic planning can be viewed as a broad managerial process of developing a vision, mission statement, goals and objectives with which to serve as influential guides to employees using the top bottom management approach, Warner (2000). He looks at a vision as "a short, succinct, and inspiring statement of what the organization intends to become and to achieve at some point in the future, often stated in competitive terms". According to Strange and Mumford (2002), a vision involves a set of beliefs about how people should act, and interact, to make manifest some idealized future state. They further argued that a vision might contain commitment to: creating an outstanding value for customers and other stakeholders; developing a great new product or service; and/or developing a great company.

Warner (2002) looks at a mission statement as an organization's vision translated into written form. It makes concrete the leader's view of the direction and purpose of the organization. He posts that the major outcome of strategic planning and strategic road mapping, after gathering all necessary information, is the setting of goals for the organization based on its vision and mission statement. Therefore, having well-defined visions, mission statements and goals changes nothing except if executives are seen to live with them, and constantly communicate them to their employees.

Changes in consumer taste, temporary interruptions in raw material supplies or even worldwide economic recessions may force a firm into making operational changes in an effort to cope with market realities. In such circumstances, staff reduction, lighter inventory control, cost control and reduction techniques are some of the more likely options, which the firm can resort to. Yet, these constitute actions that are useful only in the short-term.

The financial sector of every economy is regarded as a nation's heartbeat. It comprises the banking, insurance, mortgage, and capital market sub sectors. To this end, the focus of this research is to establish whether Bank of Baroda Kenya Limited engages in strategic planning.

Various financial institutions, therefore, need to come up with the application of innovative ideas to create unique brands, customer-friendly products/services that will bring about brand preference and customer confidence. To this effect, this 
research attempts to analyze empirically how strategic planning can be used by Bank of Baroda Kenya Limited effectively to derive plans for growth and development.

The basis of strategic planning was to enable all organizations satisfy their customers' needs and to maximize profit. In other words, this study brought about an increasing awareness in the application of strategic planning by organizations. Since desperate situations require desperate measures, this study aimed to seek out how strategic planning helped to improve Bank of Baroda Kenya Limited services, improve on parameters for evaluation of the bank by owners, customers and regulatory authorities.

The study was meaningful, not only to Bank of Baroda Kenya Limited but also to other banks operating in the banking industry, as well as other players in the financial sector as a whole. Its benefit to Bank of Baroda Kenya Limited would come from the study's critical analysis of the bank's strengths and weaknesses as well as possible and foreseeable opportunities and threats in the coming future.

\section{The Hypothesis}

There is no correlation between the levels of strategic planning on marketing, technological and financial performance.

\section{Scope and Limitation}

This study focused on the Bank of Baroda (India) Ltd as established in Kenya and was limited to the amount of work involved. The strategic plans and other materials of the organizations were strongly held as confidential information; hence assessing them was a major limitation.

The cost of travelling to and from the organization was another limitation. Also some respondents were unwilling to cooperate.

\section{Methodology}

The study employed descriptive design, which was designed to describe the features/behavior of particular phenomena in an accurate and systematic way; allowing the description and interpretation of the existing relationship and comparison of variables under study. Qualitative and quantitative data was collected from Primary and Secondary sources. It allowed the researcher to formulate tentative solutions that may be of significance to the existing gap. Survey studies were used to identify problems/justify current conditions and practices, make comparisons as well as to determine what others are doing with similar gaps and benefits from their experiences in making plans and decisions. Correlation research design was used to describe the statistical association between two or more variables, because it was vital for the researcher where rigorous experimental approach was not possible and which helped to determine the relationship among variables with high degree of accuracy, Kothari (2009).

The respondents were drawn from 10 branches of Bank of Baroda Kenya limited, located in Nairobi, Mombasa, Kisumu, Nakuru, Eldoret, Thika and Kakamega. The managers are mainly concerned with formulating strategic plans with the implementation of the strategies and executions.

\section{Data Processing and Analysis}

Data were collected from March $16^{\text {th }}, 2012$ to April 30 $0^{\text {th }}$, 2012. Several methods were used to collect data. This process entailed administering questionnaires, conducting interviews, and review of documented information like financial reports; from the bank managers, opinions and observations mainly from customers and bank activities. Questionnaires from each department of the bank were delivered from March $17^{\text {th }}$ to march $24^{\text {th }}$ and were collected from March $28^{\text {th }}$ to March $30^{\text {th }}$, 2012. The collected data was examined, edited, coded and analyzed with the aid of statistical package of social science (spss) version 11.5. Interviews were controlled to ensure relevance and accurate information was captured. Qualitative data were analyzed in narrative form while quantitative data were analyzed using frequencies and percentages. Findings were presented and discussed based on study objectives. Graphical illustrations were used to present the data and results findings. Research findings and conclusions of the study were drawn with the help of the information obtained from the questionnaires, interview schedules and from analysis of documents.

\section{Results}

The determination of coefficient of correlation between 2002 and 2003

Table 4

\begin{tabular}{|l|l|l|l|l|l}
\hline Description & $\begin{array}{l}2002 \\
(\mathrm{X})\end{array}$ & $\begin{array}{l}2003 \\
(\mathrm{Y})\end{array}$ & $\mathrm{XY}$ & \multicolumn{1}{|c|}{$\boldsymbol{X}^{\mathbf{2}}$} & \multicolumn{1}{|c|}{$\boldsymbol{Y}^{\mathbf{2}}$} \\
\hline $\begin{array}{l}\text { Shareholders' } \\
\text { funds }\end{array}$ & 415.20 & 823.30 & $341,834.16$ & $172,391.04$ & $677,822.89$ \\
\hline Total assets & $4,997.00$ & $7,998.00$ & $39,966,006.00$ & $24,970,009.00$ & $63,968,004.00$ \\
\hline Deposits & $4,465.00$ & $7,050.00$ & $31,478,250.00$ & $19,936,225.00$ & $49,702,500.00$ \\
\hline Advances & $1,681.00$ & $2,042.00$ & $3,432,602.00$ & $2,825,761.00$ & $4,169,764.00$ \\
\hline $\begin{array}{l}\text { Business/emp1 } \\
\text { oyee }\end{array}$ & 48.79 & 73.32 & $3,577.28$ & $2,380.46$ & $5,375.82$ \\
\hline Net Profit & 33.00 & 32.00 & $1,056.00$ & $1,089.00$ & $1,024.00$ \\
\hline $\begin{array}{l}\text { Operating } \\
\text { profit }\end{array}$ & 54.00 & 167.00 & $9,018.00$ & $2,916.00$ & $27,889.00$ \\
\hline $\begin{array}{l}\text { Book } \\
\text { Value/Share }\end{array}$ & 26.75 & 24.95 & 667.41 & 715.56 & 622.50 \\
\hline & $11,720.7$ & 18210.5 & $75,233,010.86$ & $47,911,487.07$ & $118,553,002.21$ \\
\hline
\end{tabular}




$$
r=\frac{\sum X Y}{\sqrt{X^{2}+Y^{2}}}
$$

Where $r$ is the correlation coefficient, $\mathrm{X}$ represents financial position of the bank in the year 2002, Y represents financial position of the bank in the year 2003

Therefore, $\quad r=\frac{75,233,010}{\sqrt{47,911,487 \times 118,553,002}}$

$r=1.00$

The coefficient of correlation 1.0 indicated a strong relationship between strategic planning and bank performance. The positive impact was attributed by economic expansion, marketing, good financial management, sustainability of agriculture growth and other internal and external factors that favored the banks strategic plan on financial performance increased profit growth, assets, customers and shareholders fund. This reflected a strong relationship on the banks strategic planning on financial performance.

The determination of coefficient of correlation between 2004 and 2005

Table 4.1

\begin{tabular}{|l|l|l|l|l|l|}
\hline Description & $2004(\mathrm{x})$ & $2005(\mathrm{Y})$ & $\mathrm{XY}$ & $\mathrm{X}^{2}$ & $\mathrm{Y}^{2}$ \\
\hline Shareholders' funds & 968.5 & 1068.5 & 1034842.25 & 937992.25 & 1141692.25 \\
\hline Total assets & 8335 & 9265 & 77223775 & 69472225 & 85840225 \\
\hline Deposits & 7168 & 8082 & 57931775 & 51380224 & 65318724 \\
\hline Advances & 2952 & 3780 & 11158560 & 8714304 & 14288400 \\
\hline $\begin{array}{l}\text { Business/employe } \\
\text { e }\end{array}$ & 79.06 & 91.2 & 7210.272 & 6250.4836 & 8317.44 \\
\hline Net Profit & 98 & 202 & 19796 & 9604 & 4084 \\
\hline Operating profit & 305 & 248 & 75640 & 93025 & 61504 \\
\hline $\begin{array}{l}\text { Book } \\
\text { Value/shares }\end{array}$ & 29.37 & 32.39 & 951.2943 & 862.5969 & 1049.1121 \\
\hline Totals & $19,934.93$ & $22,769.09$ & $147,452,550.82$ & $130,614,487.33$ & $166,700,715.80$ \\
\hline
\end{tabular}

Source: Researcher

$$
r=\sum_{\sqrt{x^{2}} x y^{2}} x y
$$

Where $\mathrm{r}$ is the correlation coefficient, $\mathrm{X}$ represents financial position of the bank in the year 2004, Y represents financial position in the bank in the year 2005.

Therefore,

$\mathrm{R}=0.99928153$

According to the findings from the above table the bank slowed down in 2005 negative correlation due to referendum politics, however due to good economic growth in agriculture, manufacturing, transport, communication as well as tourism, there was steady growth showing positive strategic planning effects on the strategies employed by the management to contain good economic prospects in the banking sector improved its asset quality portfolio. However, it was found out that capital adequacy ratio declined during the period, though it managed to remain stable. The management maintained good growth in deposits and profitability by use of strategic by the bank management. The improved performance indicated outcome of increased income on loans and advances and a significant inflow of foreign deposits. Strategic planning towards customer convenience through anywhere banking and moving premises like Head quarter from Tom Mboya Street to Koinange street, from pioneer House in town centre to Enterprise Road Industrial area, reengineering had resulted in efficiency and increased business volumes. It was found out that through positive relationship between strategic planning and financial performance, performance outcome increased reduction on non-performing loans to gross loans. The reduction in the level of nonperforming loans was attributed to positive strategic planning to recoveries and write-offs. Net profit also significantly improved according to the findings. All these outcomes were due to strategic planning on corporate governance that had complied with applicable laws and regulations of the banking companies as applied by the management of the bank. 
The determination of coefficient of correlation between 2006 and 2007

Table 4.2

\begin{tabular}{|l|l|l|l|l|l|}
\hline Description & $2006(\mathrm{X})$ & $2007(\mathrm{Y})$ & $\mathrm{XY}$ & $\boldsymbol{X} \mathbf{2}$ & $\boldsymbol{Y} \mathbf{2}$ \\
\hline Shareholder s' funds & $1,263.00$ & $1,583.00$ & $1,999,329.00$ & $1,595,169.00$ & $2,505,889.00$ \\
\hline Total assets & $11,773.00$ & $14,759.00$ & $173,757,707.00$ & $138,603,529.00$ & $217,828,081.00$ \\
\hline Deposits & $10,122.00$ & $12,673.00$ & $128,276,106.00$ & $02,454,884.00$ & $160,604,929.00$ \\
\hline Advances & $4,600.00$ & $7,203.00$ & $33,133,800.00$ & $21,160,000.00$ & $51,883,209.00$ \\
\hline Business/em ployee & 115.02 & 153.52 & $17,657.87$ & $13,229.60$ & $23,568.39$ \\
\hline Net Profit & 261.00 & 365.00 & $95,265.00$ & $68,121.00$ & $133,225.00$ \\
\hline Operating profit & 389.00 & 569.00 & $221,341.00$ & $151,321.00$ & $323,761.00$ \\
\hline Book Value/Share & 38.26 & 46.45 & $1,777.18$ & $1,463.83$ & $2,157.60$ \\
\hline & $28,561.28$ & $37,351.97$ & $337,502,983.05$ & $264,047,717.43$ & $433,304,819.99$ \\
\hline
\end{tabular}

Source: Researcher $\mathrm{r}=\frac{\sum X Y}{\sqrt{X^{2}+Y^{2}}}$

Where $r$ is the correlation coefficient, $X$ represents financial position of the bank in the year 2006, Y represents financial position of the bank in the year 2007

$$
337,502,983
$$

Therefore, $r=\sqrt{\sqrt{264,047,717 \times 433,304,820}}$

$\mathrm{r}=0.998$

The coefficient of 0.998 indicates a strong positive relationship between strategic planning and financial performance of the bank. The positive growth was attributed to good economic growth during this period contributed agriculture, manufacturing and service sector such as financial services, transport, telecommunications and tourism, and may be most sectors had positive growth prospects or low inflation mainly on account of lower prices of the food, non-alcoholic drinks, goods and services.

The determination of coefficient of correlation between 2008 and 2009

Table 5

\begin{tabular}{|l|l|l|l|l|l|}
\hline Description & $2008(\mathrm{x})$ & $2009(\mathrm{Y})$ & $\mathrm{XY}$ & $\mathrm{X}^{2}$ & $\mathrm{Y}^{2}$ \\
\hline Shareholders funds & 1910 & 2565 & 4899150 & 3648100 & 6579225 \\
\hline Total assets & 18361 & 21940 & 402840340 & 337126321 & 481363600 \\
\hline Deposits & 15166 & 18634 & 282603244 & 230007556 & 347225956 \\
\hline Advances & 9364 & 9543 & 89360652 & 87684496 & 91068849 \\
\hline Business/employee & 180.37 & 193 & 34811.41 & 32533.3369 & 37249 \\
\hline Net Profit & 434 & 524 & 227416 & 188356 & 274576 \\
\hline Operating profit & 850 & 778 & 661300 & 722500 & 605284 \\
\hline Book Value/shares & 38.61 & 51.84 & 2001.5424 & 1490.7321 & 2687.3856 \\
\hline Totals & 46303.98 & 54228.84 & 780628915 & 659411353.1 & 927157426.4 \\
\hline
\end{tabular}

$$
r=\frac{\sum x y}{\sqrt{x^{2} x y^{2}}}
$$

Where $\mathrm{r}$ is the correlation coefficient, $\mathrm{X}$ represents financial position of the bank in the year $\bullet 2008$, Y represents financial position in the bank in the year 2009 Therefore, $r=0.9928 \mathrm{r}=0.9928$

There was a strong relationship between strategic planning and financial performance. The positive outcome was that bank increased new customers, growth of shareholders fund, net profit growth, customer deposits as indicated on the table. According to the findings the growth was attributed to increased strategic management strength on economic activities of the bank in the households and corporate sectors. Branch network grew despite 2008 hurdles (election violence) the bank registered significant growth in assets base, supported by growth in deposits, injection of capital and retention of profits. The bank registered high capital adequacy and liquidity ratios and a decline in the level of nonperforming loans. It was also found that bank had successfully implemented antimony laundering software compulsory for all international banks, agreeing with Mbwayo (2005) on strategies applied by commercial banks in antimoney laundering compliance programme that strict adherence procedures and standards had been implemented to ensure money laundering was contained in Kenya. As part of corporate social responsibility strategic plans, the bank donated food items and school bags to 200 destitute student in Mombasa.

This was possible due to financial stability to the bank on it is strategic planning on financial performance. As coined by Kaplan and Norton (1995) financial initiative. Due to good strategic planning on financial performance indicators, It was found out that the bank bagged the first runner up as the " best bank among ' $\mathrm{B}$ ' category banks " with asset size between Ksh. 5 billion for year 2008 and was awarded one more feather in its cap and awarded second runner up as " most efficient bank" for year 2008. And in the year 2009 under bank's corporate social responsibility, it was observed that through strategic planning performance the bank was financially stable, and this enable the bank to spend its funds to donate 
computers to school for instance A.I.C secondary school and the bank was awarded the award for the best bank in Tier 11 category.

This agrees with Kaplan and Norton on BSC on the financial and business perspectives. Based on business perspective, it allows managers to know how well their business is running, and whether its product and services conform to customers the (Mission) agreeing with bank of Borada. According to Mbwayo (2000) financial and capital plans identify both services and uses of funds, including direction for capital allocation and spending also agreeing with bank of Baroda based on the following : - bank of Baroda identify its capital and financial plans sources that is from its customers and after finding the funds through revenue, customer deposit and profits, it uses them to buy computers and donate to school and food items to deserving communities based on their needs for example donation of wheelchairs to disable people.

The determination of coefficient of correlation between 2009 and 2010

Table 5.1

\begin{tabular}{|l|l|l|l|l|l|}
\hline Description & $\begin{array}{l}2009 \\
(\mathrm{X})\end{array}$ & $2010(\mathrm{Y})$ & $\mathrm{XY}$ & $\boldsymbol{X} \mathbf{2}$ & $\boldsymbol{Y} \mathbf{2}$ \\
\hline $\begin{array}{l}\text { Shareholder } \\
\text { s' funds }\end{array}$ & $2,565.00$ & $4,744.00$ & $12,168,360.00$ & $6,579,225.00$ & $22,505,536.00$ \\
\hline Total assets & $\begin{array}{l}21,940.0 \\
0\end{array}$ & $31,332.00$ & $687,424,080.00$ & $481,363,600.00$ & $981,694,224.00$ \\
\hline Deposits & $18,634.0$ & $25,600.00$ & $477,030,400.00$ & $347,225,956.00$ & $655,360,000.00$ \\
\hline Advances & $9,543.00$ & $18,830.00$ & $179,694,690.00$ & $91,068,849.00$ & $354,568,900.00$ \\
\hline $\begin{array}{l}\text { Business/em } \\
\text { ployee }\end{array}$ & 193.00 & 252.76 & $48,782.68$ & $37,249.00$ & $63,887.62$ \\
\hline Net Profit & 524.00 & $1,393.00$ & $729,932.00$ & $274,576.00$ & $1,940,449.00$ \\
\hline $\begin{array}{l}\text { Operating } \\
\text { profit }\end{array}$ & 778.00 & $1,883.00$ & $1,464,974.00$ & $605,284.00$ & $3,545,689.00$ \\
\hline $\begin{array}{l}\text { Book } \\
\text { Value/Share }\end{array}$ & 51.84 & 95.86 & $4,969.38$ & $2,687.39$ & $9,189.14$ \\
\hline & $54,228.8$ & $84,130.62$ & $1,358,566,188.06$ & $927,157,426.39$ & $2,019,687,874.76$ \\
\hline
\end{tabular}

\section{Source: Researchers}

$$
\mathrm{r}=\frac{\sum X Y}{\sqrt{X^{2}+Y^{2}}}
$$

Where $\mathrm{r}$ is the correlation coefficient, $\mathrm{X}$ represents financial position of the bank in the year 2009, Y represents financial position in the bank in the year 2010

Therefore,

$$
r=\frac{1,358,566,188}{\sqrt{927,157,426 \times 2,019,687,875}} \quad r=0.9928
$$

The coefficient of correlation was 0.9928 , indicating positive relationship between strategic planning on financial performance of the bank. The pace of economic expansion was sustainable and the increase in output was attributed to the rainfall experienced, which might have affected positively on agriculture and electricity generation. May be inflation went down. Tourism industry grew strong during this period because of severe winter in Europe and KTBS marketing of the country and due to stability in the country, reflected a strong correlation between strategic planning on financial performance of the bank.

According to Runy (2005) how to allocate resources is perhaps one of the most difficult decisions executives have to make and strategic planning process incorporates strategic planning financial,, operational planning and capital allocation, while Blaine notes that a strategic plan without financial backing is not much of a strategy and went further to say that "a financial plan without a strategy is not much of a plan."

Bank of Baroda's strategic plan on financial performance had the following impacts: through dedication of the board of directors/management and corporate governance, over the years dated back to 2006 up to 2010 there is a steady increase on the firms finance performance in business volumes, profit growth, book value per share, total assets, business per employees and shareholders' funds.

Shareholders' funds increased from ksh.1263.1 million in 2006 to 4744 million in 2010. It was observed that through leadership competencies' of banks executive and well trained accountants and the general staff motivation who implements the strategic plans enable that bank to keep a steady growth in their financial performance. Shareholders interest .according to the findings were catered for:- which created positive attitudes of an outstanding bank of Baroda employees to build on the facts of reality and their ability to reason and are capable of achieving both success and happiness of Bank of Baroda. 
Business volume: according to the findings on the corporate level, through the balanced scored card as adopted by Kaplan and Horton, on the business initiatives, through strategic planning on financial performance influence of strategic planning impacts positively on the business initiative

Baroda bank had steadily increased its business volume and revenue, by identifying her client' legitimate financial needs and finding a way to help them achieve their economic goals by providing the right products and services, due to their initiatives its business volume had increased steadily as shown on the graph. From 2006, it increased its deposits from ksh 10,122 million to 25600 million in 2010. While its advance increased from ksh.4, 600 million in 2006 to 18830 in 2010. This was made possible due strategic plans on use of technology, internet service, e-banking, pesa point and telecommunication technologies adopted by the bank to meet its strategic objective (good marketing) of Bank of Baroda also according to the findings, like as individual had a set of values to guide their actions of attributes, which optimize their performance towards their goals. They provide fundamental insight to help clients achieve their economic goals and solve their financial problems; they have skilled financial advice business that increases their business volumes. Responsive Bank of Baroda's clients get an answer quickly as possible even when the answer is no, impacting positively to customers, thus building customer confidence and shareholders to invest more in the Bank [deposits].

Reliability of bank of Baroda, their customers are selected as long term partners and are treated accordingly. This makes bank of Baroda to continue to earn the right to be called the reliable bank.

Due to strategic planning on financial performance, it had the following effects in financial performance as per the findings in 2006 from ksh.389 million to 850 in 2008. But due to the effects of 2007/o8 general elections disputes and ICC issue it declined in 2009 to ksh.778 million and went up to ksh.1,883 million on 2010. It was observed that all these decreases and increases of net and operational profits were due to emergent and intended strategic plans in finance performance by the bank.

For the period 2006 up to 2010, the band showed a steady growth/increased Assets indicating positive relationship between strategic planning on financial performance, in both tangible and intangible assets up to $48 \%$ increases of assets in 2010. This was made possible due to good governance, good Public Relation, and good strategic planning by Bank Managers.

Business per employee increased to kshs.252.76 million from ksh.115.02 million in 2006. This indicates positive relationship between strategic planning on financial performance of the bankthrough use of staff trainings, use of IT, good relationship with the government, employees' motivation and good marketing strategic adopted by the bank as well as improved corporate governance of the bank.

Book value per share as shown on the graph increase from ksh.38.26 million in 2006 to ksh.45.45 million in 2007 , but due to December 2007 election violence, investors felt insecure to trade in stock exchange, this caused decline in book value per share, in 2008 to ksh.38.61million. However when the country returned to normal operations, book value rose to ksh.51.84 million in 2009 and up ksh.95.86 million respectively. Indicating that in 2008, there was negative correlation between the bank's strategic planning on financial performance, relation to external pressure such as political environment, and the relationship that exists on the bank's strategic planning on financial performance of bank of Baroda. This agrees with marks (1980) that strategy and structure follow people on the other hand it agrees with Kaplan and Norton (1995) on the BSC on the financial perspective leads to the unbalanced situation as in 2008 with regard to other perspectives.

\section{Discussion}

Based table 4 , the coefficient of correlation 1.0 indicates a strong relationship between strategic planning and bank performance. According to the findings as shown by table 4.1, the bank slowed down in 2005 negative correlation due to referendum politics, however due to good economic growth in agriculture, manufacturing, transport, communication as well as tourism, there was steady growth showing positive strategic planning effects on the strategies employed by the management to contain good economic prospects in the banking sector improved its asset quality portfolio.

The parameters used for assessment includes Strategic planning on Marketing performance, on financial performance and technological performance. The purpose was to determine whether there was correlation between strategic planning and the above parameters. The aggregate mean rating on market performance was 3.25 which means that most of the respondents were satisfied but there is room for improvement. The coefficient of correlation $(r=1.00)$ which means there is very strong correlation between strategic planning and financial performance. The aggregate rating for technology was 3.23 which mean the relationship between strategic planning and technology was satisfactory but needs to improve particularly in responding to changes in technology which was rated as 2.08 .

On overall the researcher found out that there was a correlation between strategic planning and Marketing, Financial, Technological performance.

\section{Conclusion}

The primary research objective of the research was to examine the relationship of planning to the financial performance, marketing, and technological performance of small and mid-sized financial institutions. Based upon the industry norms 
for satisfactory performance stated in the Introduction, the survey respondents and the sample population were both above and slightly below the norm as related to return on Assets, profit growth, business volumes, shareholders' funds, and book value per share and business per employee.

\section{Recommendation}

The potential correlation between sound planning, as a management tool, and the overall performance of the organization, as indicated by several of the studies mentioned earlier, needs to be more clearly delineated in the minds of employees at all levels of the organization. In the training process, it may be necessary to clarify more clearly the linkage between the successful attainments of individual goals to the overall attainment of organizational goals.

The findings of this study revealed that there was correlation between the level of planning activities carried out by a financial institution and the performance of the bank as measured by the Return on Assets, the Return on Equity, and the Net Interest Margin, customer satisfaction, quality of services, product quality, brand, brand name, time frame, costs, efficiency and effectiveness. The findings also revealed that there was correlation between the level of planning carried out by the financial institution and the management characteristics measured. The findings also found correlation between the level of planning carried out and the size of the bank's departments within the target population. These results were consistent and reaffirmed several prior studies indicating that there was correlation between the level of impacts of strategic planning and performance of the bank output.

\section{REFERENCES}

[1].Andison Wesley. (1998). strategic management and business policy.

[2].Anderson, T.J. (2000). Strategic Planning, Autonomous Actions and Corporate Performance. Long-range planning,33, (2). $184-200$.

[3].Cadotte, E. R., Woodruff, R. B., Jenkins, R. L. (1987). "Expectations and Norms in models of consumer satisfaction.” Journal of market research.

[4].Capon, N., Farley, J., \& Hulbert, J. (1994). Strategic Planning and Financial Performance: More Evidence. Journal of management studies, 31. $105-110$.

[5].Calloway. (1991). Executive Search Review

[6].Churchill G. A. and Suprenant C. (1992). "An investigation into the determinant of customer satisfaction" Journal of marketing research.

[7].Fred R. David. (2007). Strategic Management. Concepts and Cases. Prentice - Hall of India, private Ltd.

[8].Glaister, K.W., \& Falshaw, R. (1999). Strategic Planning: Still Going Strong? Long range planning, 32. (1). 107 116.

[9].Hopkins, W.E., \& Hopkins, S.A. (1997). Strategic Planning - Financial Performance Relationships in Banks: a Casual Examination. Strategic management journal, 18. (8). 635 - 652.

[10]. John a. pearce11, Richard B. Robinson, Jr. (2008). Strategic Management; Formulation, Implementation, and Control, Tata Mcgraw -Hill publishing Company Ltd NewDelhi.

[11]. Kothari C.R. (2009). Research methodology methods and techniques. New age international (P) limited.

[12]. Khalifa, M. and Liu, V. (2003). "Determinants of Satisfaction at different adoption stages of internet-based services" Journal of the association for information systems.

[13]. Kotelnikov, Vadim. (2007). "Strategic management: Modern Approaches to the new rapidly changing innovationdriven economy".culled from www.1000ventures.com.

[14]. Kotler, Phillip. (2004). "Marketing Management".

[15]. Mark Jenkins. (2002). strategic management, a multipurpose perspective.

[16]. Mugenda O M etal. (1999). Research methods quantitative and qualitative approaches. ACTS press (African centre for technology studies). Nairobi.

[17]. Mckinney V, Yoon K, Zahedi, F. m. (2002). “The measurement of web customer satisfaction: An expectation and Disconfirmation Approach" Information system research.

[18]. Mertzberg. (1995). Olukanye, C. A (2001): "Banking and Finance in Nigeria" 4th edition, University of Abuja; pp $83-85$

[19]. Nandan Srivanstava. (2010). "Bobmatri” Journal.

[20]. Oliver R. L. (1980). “A cognitive model of the antecedents and consequences of satisfaction decisions.” Journal of marketing research, Vol. XVII, November.

[21]. Parasuraman, A. Zeithaml, V. A., and Berry, L. L. (1985). "A conceptual model of service quality and its implications for future research." Journal of marketing.

[22]. Pearce \& Robinson. (2005). Strategic Management. Formulation, Implementation, and Control. $9^{\text {th }}$ edition. McGraw - Hill.

[23]. Porter M. (1990). The competitive advantage of nations. $5^{\text {th }}$ edition Palgrave. New York.

[24]. Powell T.C. et al. (1997). Information technology as competitive advantage. The role of human, business, and technology resources. Bryant College, USA (journal)

[25]. Ruocco, P. \& Proctor, T. (1994). Strategic Planning In Practice: a Creative Approach. Marketing intelligence and planning, 12. (9). $24-29$

[26]. Rogers, P.R., Miller, A., \& Judge, W.Q. (1999). Using Information - Processing 
[27]. Theory to Understand Planning/Performance Relationships in the Context of Strategy. Strategic management journal, 20. 566 - 577.

[28]. Saunders M., Lewis P. Thorhhill A.(2000). "Research methods for business students" $2^{\text {nd }}$ Edition, UK, Financial Times, Prentice Hall.

[29]. Strange, J.M \& Mumford, M.D.(2005). "the Origin of Vision Effects of Reflection, Models and Analysis" the leadership Quarterly, vol. 16 pp121-148.

[30]. Shuman, J.C., Shaw, J.J., \& Sussman, G. (1985). Strategic Planning in Smaller Rapid Growth Companies. Long range planning, 18. (6), 48 - 53.

[31]. Warner, Malcolm. (2000)."Regional encyclopedia of Business and Management: Management in Emerging Countries", an article on Management Best practices; pp169-175.

[32]. Wood, D.R., \& LaForge, R.L. (1979). The Impact of Comprehensive Planning on Financial Performance. Academy of management journal, 22. (3), 516 - 526

[33]. Watts, L.R. (1987). Small Bank Planning Practices, Ownership, Characteristics, and Performance. Ph.D. diss., Arizona State University. 